\title{
USDA
}

Animal and Plant Health Inspection Service

APHIS 81-05-014

\section{Plant Protection and Quarantine Successes in 2015 \\ Recognizing Program}

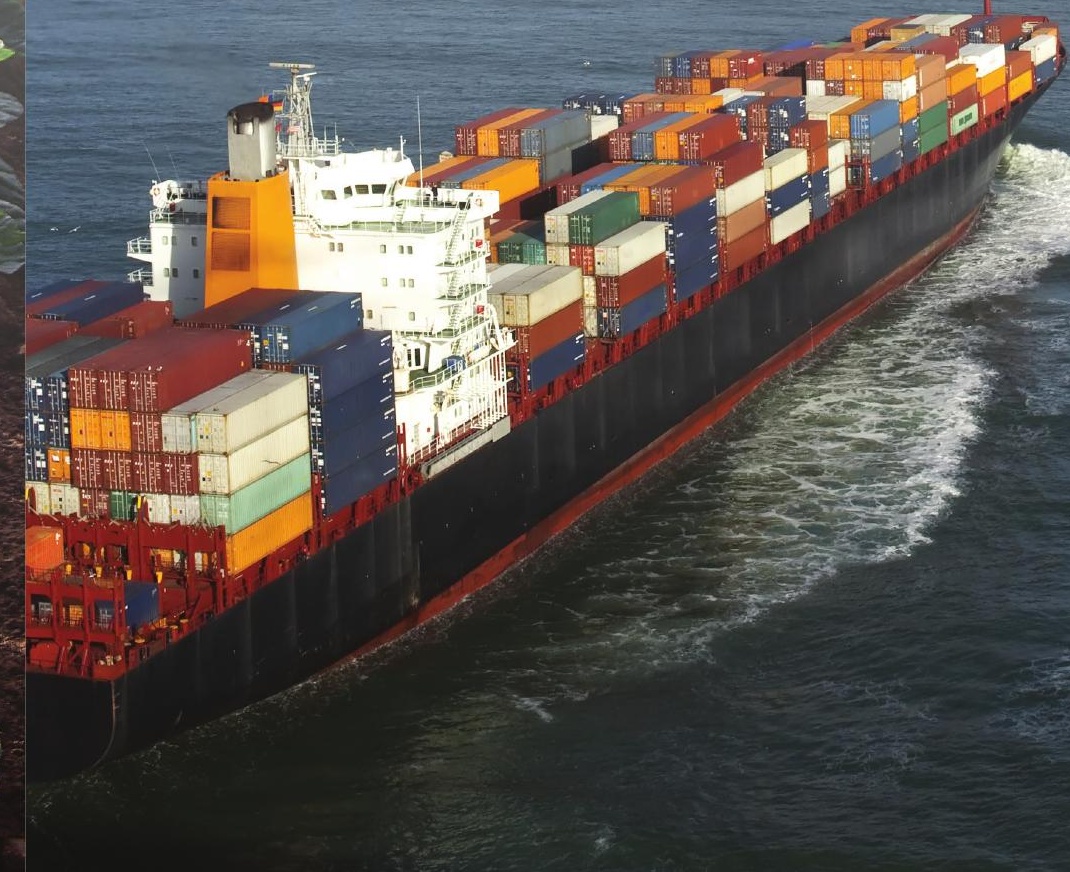





\section{Message From the Deputy Administrator}

Tn many ways, 2015 was extraordinary for 1 plant health protection. We had more new pest detections and saw higher numbers of pest outbreaks than in previous years, including the first-ever detection of old world bollworm in the continental United States and a record-setting 12 fruit fly outbreaks. Despite increased pest pressures, we detected 91 percent of outbreaks before they spread beyond the area of original colonization. We deployed more than 190 people and invested more than 30,000 work hours responding to plant health emergencies. We also eliminated plum pox virus from Niagara County, NY; kept 99.5 percent of 16 million cotton acres free from boll weevil; eradicated 82 percent of the Asian longhorned beetle (ALB) infestation in New York; and had zero detections of pink bollworm and European grapevine moth, positioning both programs to declare full eradication in 2016.

The year 2015 was also an impressive year for agricultural trade. The value of U.S. agricultural exports exceeded the value of imports again, making the last 7 years the strongest period for American agricultural exports in the history of our country. We were integral to this success. Using astute diplomacy and sound technical expertise, we worked closely with our international trading partners to reach critical plant health agreements and eliminated trade barriers to sustain and expand U.S. export markets valued at more than $\$ 2.4$ billion.
Our ability to effectively safeguard agriculture and facilitate safe agricultural trade is grounded in our commitment to continuously evaluate and constantly improve our work. This commitment is reflected in the Strategic Plan that we published 1 year ago. The plan established three goals for the next 5 years:

- Goal 1: Strengthen Plant Protection and Quarantine's (PPQ) pest exclusion system.

- Goal 2: Optimize PPQ's domestic pest management and eradication programs.

- Goal 3: Increase the safety of agricultural trade to expand economic opportunities in the global marketplace.

Thanks to the talented, dedicated men and women of PPQ and the hard work, commitment, and perseverance of our partners, cooperators, and the industries we serve, we made significant progress toward achieving these goals over the last year.

We know that there is more to do, but we are extremely proud of what we accomplished in 2015. We look forward to working with each of you in the years ahead as we continue to safeguard American agriculture and facilitate the safe trade of agricultural products.

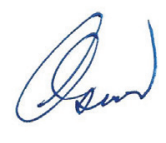

Osama El-Lissy

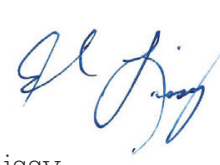

Deputy Administrator

Plant Protection and Quarantine

Animal and Plant Health Inspection Service

U.S. Department of Agriculture

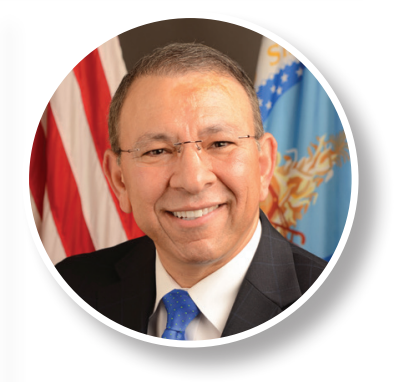




\section{Mission: Safeguarding Agriculture, Facilitating Safe Trade}

Tn today's world, U.S. agriculture and
global trade increasingly depend on one
another. According to the U.S. Department
of Agriculture's (USDA) Economic Research
Service, U.S. agricultural productivity has
grown faster than domestic food and fiber demand, causing U.S. farmers and agricultural firms to rely heavily on export markets to sustain prices and revenues. At the same time, U.S. consumer demand for more diverse foods has steadily driven up U.S. agricultural imports over the years.

While U.S. farmers and consumers have much to gain from global trade, it leaves our agricultural and natural resources vulnerable to the plant pests and animal diseases that can be moved through commerce. Since the beginning of the 20th century, PPQ has been there to safeguard those resources against the introduction and spread of damaging pests and diseases. Today, we also develop and apply measures to reduce pest risks in foreign commerce, helping to maintain our Nation's healthy agricultural systems.

Effective import regulations are central to our success. Through these regulations, we mitigate the risks posed by agricultural products long before they reach U.S. ports of entry. To develop these regulations, we conduct risk assessments that enable us to make informed decisions about the potential pest or disease risks associated with specific commodity imports. Based on these assessments, PPQ will only allow imports if they can occur in a safe manner.
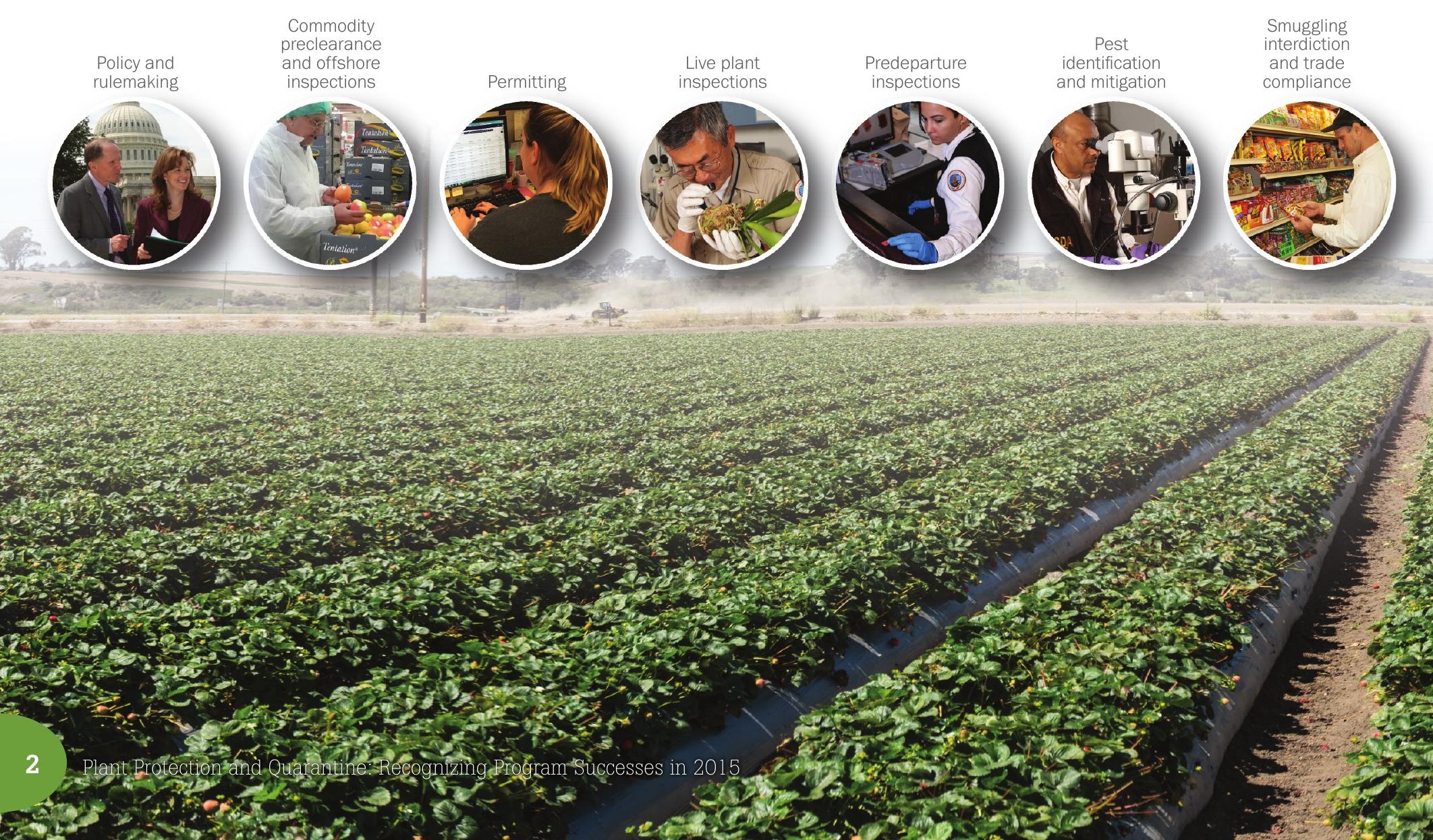


\section{Safeguarding American Agriculture}

Safeguarding is our core. It is an enormous responsibility-one that we take very seriously. To accomplish this part of our mission, we focus our work in two key areas:

\section{- Safeguarding against the entry and} establishment of pests, and

- Managing and eradicating those pests that become established.

This work spans a wide spectrum of activities-from offshore programs, rulemaking, permitting, port and border inspections, pest identification and mitigation, and smuggling interdiction and trade compliance to pest detection, response, and pest management and eradication programs.

\section{Facilitating Safe Trade}

Of equal importance is our work to make sure that billions of dollars in agricultural commodities are traded safely, without moving invasive pests and diseases through commerce. Our goal is to create a fair and predictable trade system for U.S. agricultural products by promoting science-based international and regional trade standards and eliminating unfair or unjustified trade barriers that would limit U.S. access to foreign markets. We also help U.S. exporters meet the plant health requirements of importing countries by certifying the health of U.S. exports.

Pest detection and response

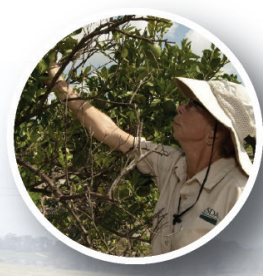

Pest eradication and management
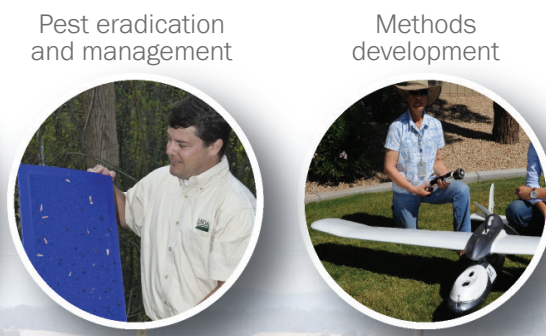

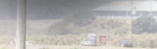

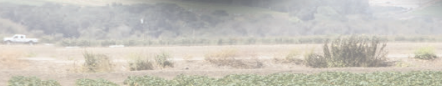

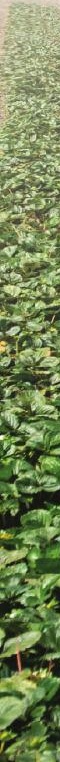

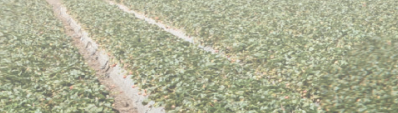
3.

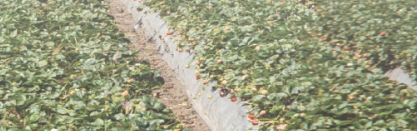

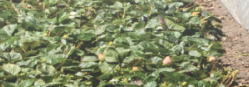

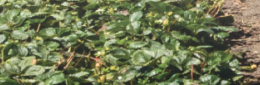

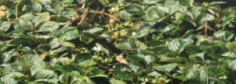

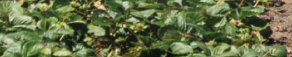
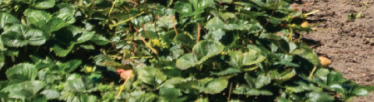



\section{Achievements and Results Strengthening Pest Exclusion}

$P \supseteq \bigcirc \begin{aligned} & \text { safeguards billions of dollars in } \\ & \text { U.S. agricultural products and }\end{aligned}$ protects nearly 600 million acres of forestland, rangelands, and other working lands against potentially devastating pests and diseases. The economic vitality of America depends on a financially strong agricultural sector and a healthy natural environment.

At the core of PPQ's safeguarding mission is its pest exclusion system-also known as Agriculture Quarantine Inspection (AQI). AQI is a continuum of pest exclusion strategies and activities that work together to minimize the plant health risks that come with global trade, international travel, and the smuggling of prohibited agricultural products. This system of overlapping safeguards begins offshore, continues through U.S. ports of entry, and extends across the Nation.

In our Strategic Plan, we established two objectives for strengthening pest exclusion:

1. More fully coordinate our pest exclusion programs and activities, making better use of the information we collect at each point along the pest exclusion continuum to target and reduce threats to U.S. agricultural and natural resources; and

2. Better focus pest exclusion programs and activities to address risks at the first opportunity-when the likelihood of pest exclusion is greatest-while applying the right level of resources and effort based on the risk presented.

\section{Progress Made \\ Improving the System}

During the last year, we took steps to enhance the management of our AQI program. We adjusted the rates we charge for AQI services after an extensive review of PPQ and U.S. Customs and Border Protection (CBP) costs and operations. This adjustment was needed to secure the program's financial footing, ensuring it could keep safeguarding our Nation's agriculture from potentially devastating pests and diseases. In addition, PPQ developed a "dashboard" application that uses AQI, domestic program, and agency financial data to generate a nearly real-time view of its safeguarding activities. As more complete and robust data become available to support the dashboard, we will be able to make better use of the information we collect to make our safeguarding programs even stronger.

We also increased communication and data sharing with CBP, strengthening our collective abilities to assess risks and take action to stop pests at our borders. This included placing a PPQ staff member full-time at CBP's Commercial Targeting and Analysis Center in Washington, D.C., a facility housing 11 Federal agencies that coordinate efforts to address import safety issues. In addition, we began implementing the new Agricultural Risk Management (ARM) system at our plant inspection stations. ARM is a workflow-based application that provides real-time data entry, tracking, and analysis of import shipments processed at these stations.

offshore, continuing through U.S. ports of entry, and extending across the Nation-to minimize the plant health risks that come with global trade, international travel, and agricultural smuggling. 
This system, when fully implemented, will give PPQ and CBP quick access to emerging pest trends associated with propagative plant imports. To better coordinate analytic efforts across PPQ, we launched a new data analytics tool called CHARTS-short for Clearinghouse Analytics Request Tracking Service. With this tool, employees and State and Federal partners can request data on imports, exports, and domestic trade to inform their decisions.

In addition, we continued streamlining regulatory processes and improving permitting procedures to better meet stakeholder needs. For example, we cut the overall time required to process regulated organism and soil movement permits by 11 days, a 23-percent reduction. By transitioning from paper shipping labels to downloadable
In 2015, we continued to push our focus offshore, increasing our capacity to address pest threats where they originate.

]
electronic labels, we eliminated the need to print and mail physical labels to importers, saving PPQ \$351,000 in annual labor costs. Importers can now email the electronic file to their shippers, saving these stakeholders an estimated $\$ 125,000$ annually. These improvements greatly benefited PPQ as well as its stakeholders, many of whom use PPQ's permit services every day.

\section{Increasing Our Focus Offshore}

We continued to push our focus offshore, increasing our capacity to address pest threats where they originate. By the end of 2015, we operated 30 offshore commodity preclearance programs around the world. Through our preclearance program, we inspect and treat commodities in foreign countries before they are exported to the United States to mitigate pest and disease risks. To further enhance our ability to exclude pests and diseases at their origin, PPQ strengthened its internal controls to increase consistency of preclearance inspections across all participating countries. PPQ also continued partnering with the U.S. Department of Defense (DoD) to train military personnel on agricultural regulations when they deploy to foreign locations. We also worked with DoD to inspect military equipment returning to the United States to help prevent the movement of soil, foreign animal diseases, and plants.

In other efforts, we initiated a 3-year pilot program with Australia to evaluate if, and under what conditions, oversight and operation of an irradiation program could be conducted by an exporting country's national plant protection organization. If successful, this approach will facilitate the safe trade of agricultural commodities by reducing regulatory burdens and costs for importers while continuing to safeguard U.S. agricultural and natural resources.

Closer to home, we worked with countries throughout the Caribbean region to strengthen regional safeguarding efforts. Specifically, we offered plant quarantine training, pest identification tools and surveys, and help with emergency response planning. This included expanding outreach to travelers moving between the United States and the Caribbean to raise awareness about the importance of declaring agricultural items when they arrive in the United States, helping to reduce pest threats in this high-risk pathway. And when our counterparts in the Dominican Republic notified us of a Mediterranean fruit fly detection there, we mobilized resources and offered technical support for the country's response to this plant health emergency. Through cooperation and quick action, we helped them mount a successful eradication and management program, safeguarding agriculture not only in the United States but throughout the Caribbean region. 


\title{
Case Study
}

\author{
Safeguarding Under Pressure
}

$E^{a}$ ach year, thousands of agricultural commodity shipments pass through our safeguarding system, successfully meeting the plant health requirements we've put in place to prevent harmful pests from entering our country and damaging our Nation's agricultural and natural resources. Occasionally, noncompliant or infested shipments-or the conveyances they travel in (vessels, shipping containers, trucks, railcars, trailers, and the like)-arrive at our ports of entry.

When an agricultural shipment or its conveyance is held at port because of a plant health issue, PPQ must work to release it as quickly as possible to keep commerce moving. In rapid order, we assess the risk presented by the shipment and determine what, if any, safeguarding actions could be applied to allow the shipment to enter. This is a high-stakes situation; behind every held shipment is a person or a company whose finances or livelihood will be impacted by our decision.

For example, when a shipment of spelt-a commodity that is prohibited from entering the United States from a number of countries-arrived at a U.S. port of entry, CBP placed the shipment on hold and contacted PPQ. The importing company pleaded that re-exporting or destroying this shipment would cause financial hardship. They urged us to allow this shipment and the additional containers that had yet to arrive to enter the United States.

Sensitive to the potential impacts of our decision, we conducted a preliminary pest risk analysis to better understand the plant pest risk. We also examined what safeguards, including processing, could be applied to reduce the risk. Finding at least 10 quarantine pests associated with spelt and having no reasonable way to secure the shipment for transit to a processing facility several States away, we had to reject the shipment.

While we may look for and consider alternate safeguards, science ultimately guides our decisions. When a shipment or its conveyance can be treated or reconditioned, we apply the measure and, if successful, allow the shipment to enter. When there is no adequate measure or the applied measure does not work, we refuse entry or destroy the shipment.

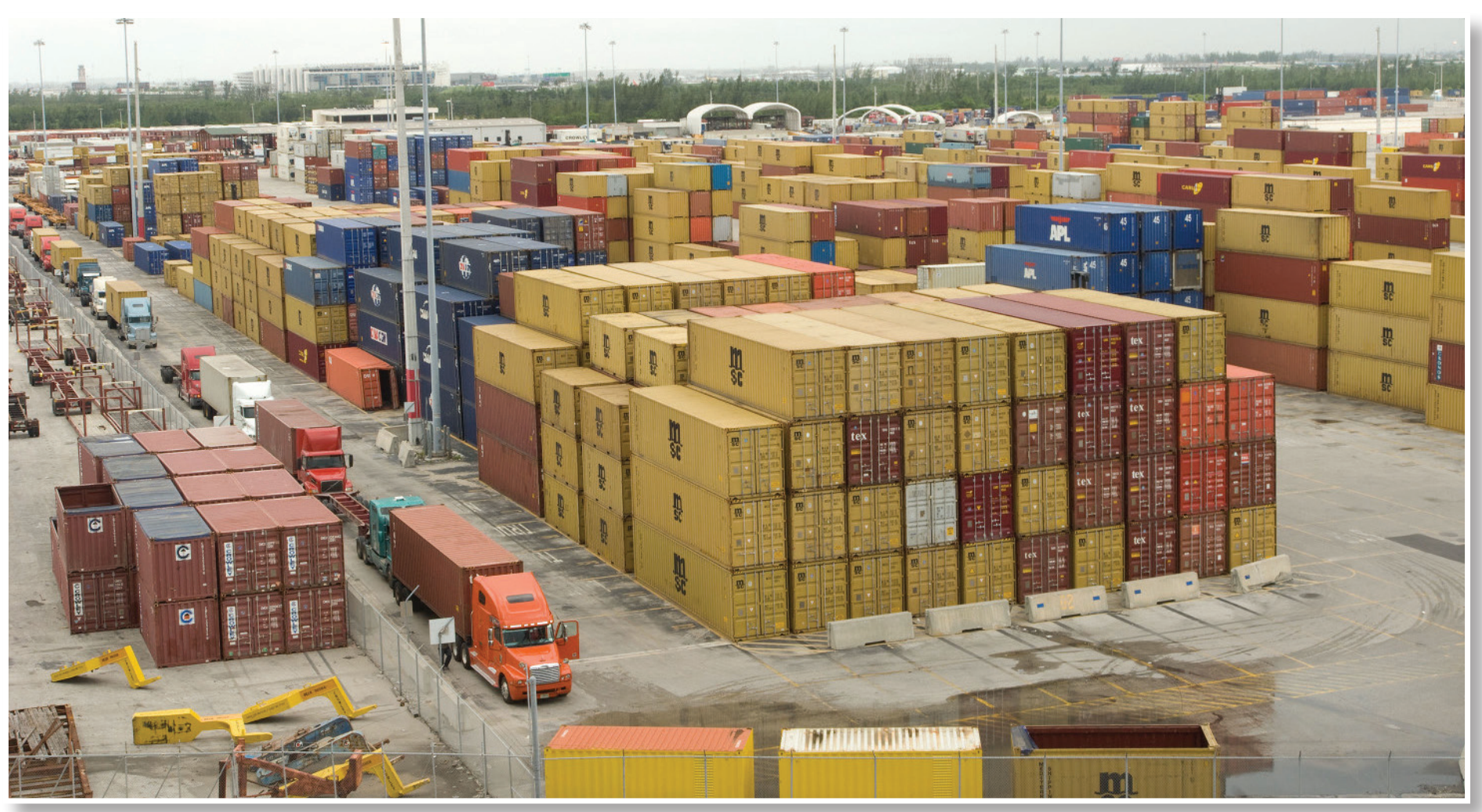


We also began working with Mexico to expand the cooperative U.S.-Canada Asian gypsy moth (AGM) program to include Mexican seaports. The AGM program, which includes an offshore ship inspection certification program for vessels coming from Far East Russia, Japan, Korea, and China, has been very effective in closing a potential pathway that could bring AGM to North America. Also, we continued working with Canada to explore opportunities to move wood packaging material inspections to the North American perimeter, which would allow us to address wood and forest pest threats before they reach our shared land border.

\section{Developing Smart Technologies, Smarter Programs}

During the last year, we tested new technologies and started using new methods to increase our ability to detect and identify pests and to make inspections of high-risk live plant shipments more efficient and effective. Specifically, we piloted the use of molecular identification technology methods at four plant inspection stations. These methods boost our ability to detect and identify to the species level pests that cannot be detected and identified visually, helping us pinpoint an appropriate regulatory action. In addition, PPQ adapted a sophisticated yet simple tool that detects specialty crop pathogens in 60 seconds or less: "CANARY," or Cellular Analysis and Notification of Antigen Risks and Yields. Two USDA plant inspection stations have piloted the rapid detection technology to test for bacterial pathogen threats to plant species. In 2015, USDA partnered with a biotechnology company to commercialize several CANARY biosensors for plant pathogen detection.

We also put in place risk-based sampling protocols in all plant inspection stations. Using these protocols, inspectors can make risk-based calculations in determining the number of samples to be inspected in each shipment; this increased the possibility of detecting pests of concern while decreasing industry wait times for inspections of lower risk shipments. Risk calculations are based on documented country-commodity action rates, pest approach rates, and shipment infestation rates, making our inspections more defensible, fair, and predictable.

In addition, we expanded the number and type of Web-based products and apps available to support the identification of plant pest arthropods, mollusks, nematodes, weeds, and diseases. We released 1 new identification smartphone app, published significant updates to 10 others, released 11 identification mobile apps for iPads, and developed 11 screening aids covering 22 species of exotic bark and wood-boring beetles. We also added thousands of new images to the imageID Web site (first released in December 2014). This searchable database now contains about 70,000 images of plant pests and commodities and is a valuable resource for pest identifiers. 


\section{Results}

\section{Offshore}

- Reduced by 90 percent the number of AGM egg masses found on ships coming to the United States from Asia as a result of technical coordination between the United States and Canada and the governments of Japan, China, and Korea

- Trained more than 1,500 foreign-deployed DoD personnel on agriculture regulations and inspected more than 700 aircraft, landing vehicles, and other equipment to help prevent soil, foreign animal diseases, and plants from entering the United States

- Closed pathways for the Internet sale of prohibited plant items among the United States, New Zealand, Australia, and Canada

\section{At the Ports}

- Inspected baggage of more than 11 million passengers and over 62,000 commodity shipments coming to the U.S. mainland from Hawaii and Puerto Rico, stopping more than 4,500 quarantine-significant pests
- Cleared more than 19,000 imported shipments containing 1.5 billion plant units and 1.5 million pounds of seeds, intercepting more than 800 reportable pests

- Conducted more than 500 treatments, eliminating pests on more than 4.2 million plant units and over 771,000 pounds of seed

- Worked with CBP's Commercial Targeting Analysis Center to identify and close 20 pathways

\section{Across the Country}

- Seized from commercial retail locations more than 290,000 pounds of prohibited plants, plant products, meat, and meat products that had entered the country illegally

- Released from quarantine more than 660 high-risk crop cultivars and germplasm from 13 different plant species, making new plant varieties available to U.S. importers and producers 


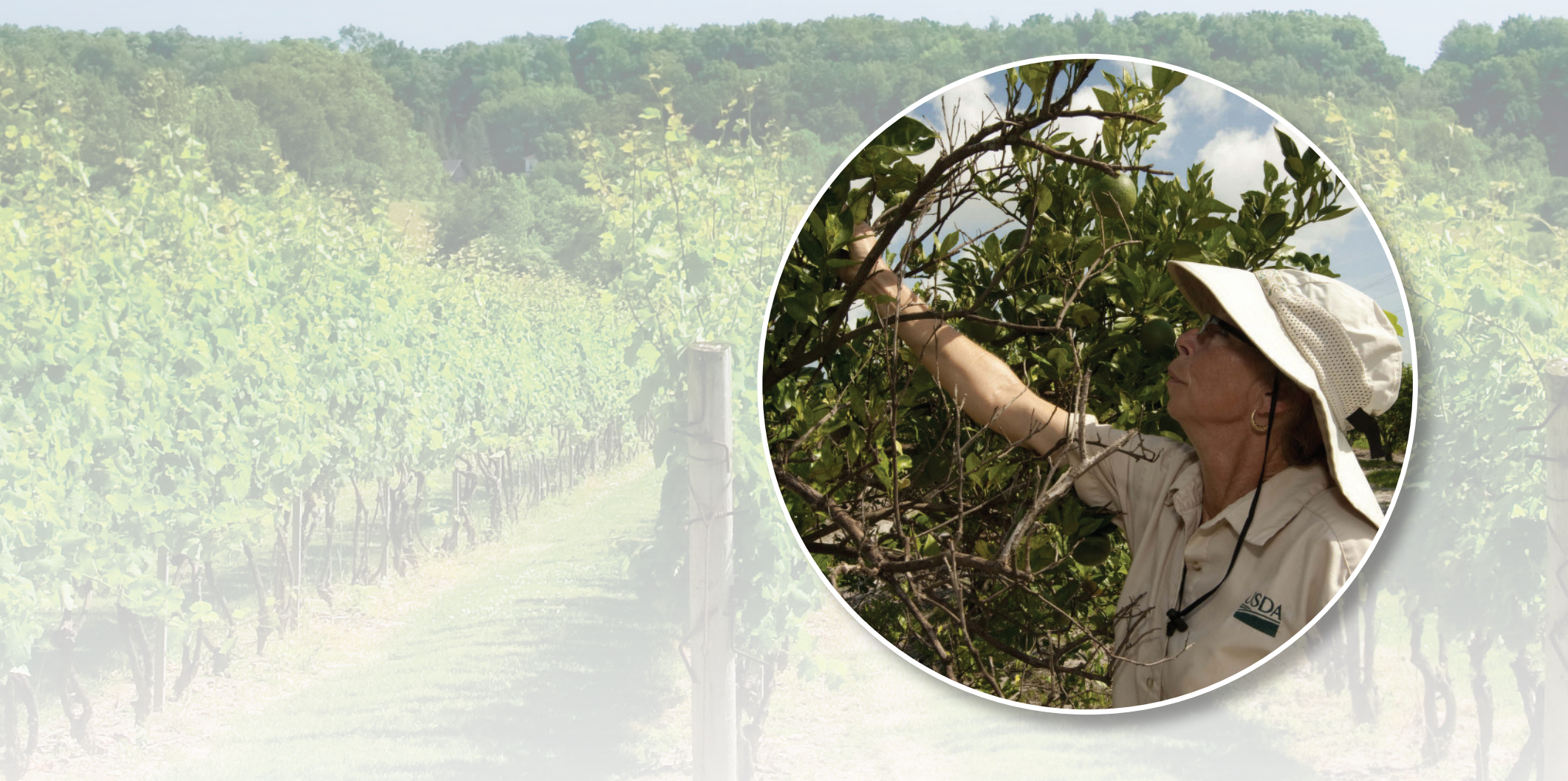




\section{Optimizing Pest Management and Eradication}

W $\begin{aligned} & \text { hen economically or environmentally } \\ & \text { significant pests become established }\end{aligned}$ PPQ works closely with Federal, State, tribal, and industry partners to reduce damage to agriculture and natural resources. Working with our many domestic partners, we have made great progress in eradicating foreign plant pests and diseases in the United States. We also continue to contain and suppress foreign pests and diseases to prevent their further spread and keep export markets open.

At the beginning of 2015, we set a goal to optimize pest management and eradication by:

Focusing the collective pest management and eradication efforts of PPQ and its partners to maximize their effect; and

- Integrating and using the unique capacities of all partners to strengthen and extend PPQ's domestic programs.

\section{Progress Made}

\section{Strengthening Partnerships}

Strategic partnerships continue to be a critical part of domestic program success. PPQ worked closely with many domestic and international stakeholders during 2015 to address plant pest and disease threats. We partnered with an international technical advisory committee and coordinated with the U.S./Mexico Boll Weevil Eradication Program Coordination Committee to develop technical strategies and harmonize efforts to eradicate boll weevil from the Lower Rio Grande Valley and neighboring Tamaulipas, Mexico.

We brought unprecedented cooperation and coordination across Federal and State agencies and industry through the USDA Huanglongbing (HLB) Multi-Agency Coordination (MAC) Group. The Group facilitated rapid and deliberate decisionmaking, allocating resources to develop and deliver near-term solutions to help the citrus industry combat HLB, one of the world's most serious citrus diseases. Through our partnerships with USDA's Agricultural Research Service, the U.S. Fish and Wildlife Service, State departments of agriculture, universities in 30 States and Territories, and 2 tribes, we evaluated and established biological control agents for numerous invasive species, including the Asian citrus psyllid (ACP), brown marmorated stink bug, emerald ash borer (EAB), ALB, hemlock woolly adelgid, and spotted wing drosophila, among others.

\section{Creating 21 st Century Pest Programs}

In 2015, we adopted, adapted, and applied modern technologies to improve program effectiveness and enhance program delivery. For example, we tested the use of remotely piloted aircraft to deliver sterile pink bollworm moths, giving us a safe, cost-effective, rapid response technology that puts us on the cutting edge in the fight against this serious pest. We also made use of common software and widely available mobile devices to enhance our pest programs and survey efforts. Specifically, we deployed iPad minis and Dell Venue tablets in our Mexican fruit fly and citrus greening $\left[\begin{array}{c}\text { In 2015, we adopted, adapted, } \\ \text { and applied modem technologies } \\ \text { to improve program effectiveness } \\ \text { and enhance program delivery. }\end{array}\right]$ programs and added a commercially available data collection tool to automate recording of ALB surveys, making data gathering and information sharing easier and more consistent. We also piloted the use of mobile devices in AGM surveys in Oklahoma and South Carolina. The use of these devices significantly improved the timeliness of survey data collection and reduced data input errors. 


\section{Improving Plant Protection Methods}

Over the last year, we made improvements to plant protection methods, generating significant benefits for PPQ and our cooperators and stakeholders. In our fruit fly programs, we improved the trapping lure, making it safer and easier to handle, and modified the sterile fruit fly rearing diet-a change that will save eradication programs more than $\$ 220,000$ annually. By developing a systems approach for the Mexican fruit fly

Over the last year, we made improvements to plant protection methods, generating significant benefits for PPQ and our cooperators and stakeholders. spreading this pest. In addition, we transferred
biological control technology to State officials
and private industry in California, allowing them
to produce more than 2 million parasitic wasps
(Tamarixia radiata) per year for use against
the ACP, a pest that spreads HLB from plant to
plant. PPQ scientists also provided Mexico with
shipments of the parasitic wasp for release
along the country's northern border.

We continued work to develop new mitigation tools for potato cyst nematode (PCN) that may serve as alternatives to methyl bromide fumigations or offer more pest control after fumigation. These alternatives include the use of trap crops (crops similar to potatoes that will stimulate nematodes to hatch but not allow them to reproduce) and fungal and biological control agents. Working with our cooperators, we piloted the trap crop in several areas in 2015. We also conducted trial releases of EAB biological control agents in 20 States, releasing more than 1.2 million parasitic wasps in 2015. The program's biological control initiative provides a promising strategy for long-term EAB management.

\section{Conducting Bigger, Better Pest Detection Surveys}

In 2015, we expanded the scope of our pest detection efforts through the Cooperative Agricultural Pest Survey and Farm Billfunded surveys. PPQ and its cooperators added 80 taxon and commodity surveys and surveyed for a total of 346 unique pests. These surveys enable us to target highrisk hosts and commodities, detect pests early to avert economic and environmental damage, gather data about pests specific to a commodity, and provide accurate assessments of pest distribution, including pest-free areas. Our assessments are vital to maintaining and expanding export markets for U.S. agricultural products.

We also improved how we target surveys. A novel clustering analysis we developed and carried out predicts geographic hot spots for ACP and HLB-infested plants, helping us find new incursions or outbreaks as early as possible. We also modified our ALB survey protocols to focus only on maple trees that are 0.5 to 1.5 miles from an infested tree. This effort increased survey efficiency and reduced costs.

\section{Providing Relief From Regulatory Burdens}

During the last year, we looked carefully at a number of ongoing pest programs to better align our regulatory response. This allowed us to reduce and, in some cases, relieve unnecessary regulatory burdens on growers and others who are subject to our regulations. For example, in consultation with the National Plant Board and industry, we decided to end enforcement of the Gladiolus Rust National Eradication and Management Plan. We determined that the organism Uromyces transversalis, also known as gladiolus rust, had spread to the limit of its natural range in the United States and can be controlled through best management practices. This 


\section{Case Study}

\section{Partners Band Together To Beat the European Grapevine Moth}

n 4 short years, the number of EGVM found in traps in

California declined by 99.9 percent-from 100,000 in 2010 to just one in 2014. In 2015, we did not detect a single moth. This success made the EGVM detection and eradication partnership one of the most effective programs in the last decade for USDA's Animal and Plant Health Inspection Service (APHIS), the California Department of Food and Agriculture (CDFA), California county agricultural commissioners, University of California Cooperative Extension (UC Coop), and growers.

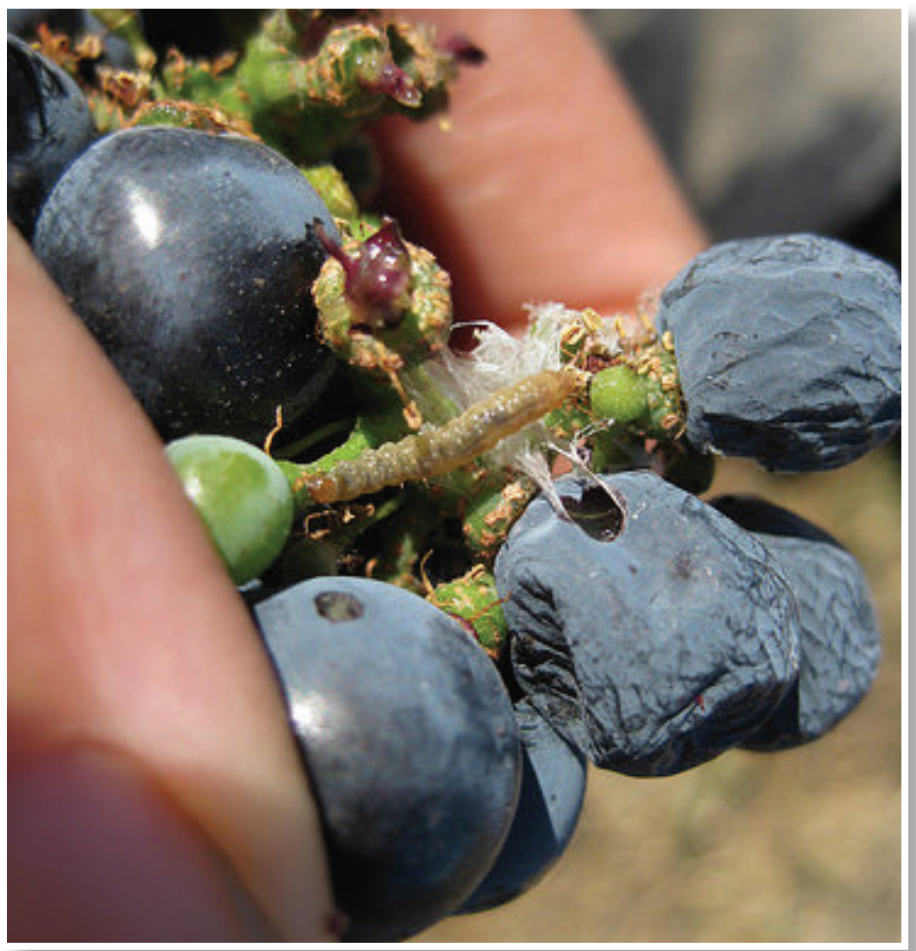

Courtesy of the Napa County Agricultural Commissioner's Office
EGVM was first detected in Napa County, CA, in 2009. Subsequent surveys detected EGVM in 11 counties in the State. The presence of this pest put fruit crops worth more than $\$ 5.7$ billion at risk and threatened to close valuable export markets for U.S. grapes and stone fruit around the world. Faced with this enormous threat, we and our partners in California moved quickly. We established the EGVM Technical Working Group, which met regularly to provide APHIS and its partners with the best available science and data to combat EGVM, and we designed an eradication program that would produce results by closely involving growers and the community. The plan called for growers to carry out pest treatments, while State and county partners set traps and lures for detection purposes and reported findings.

A key reason for success was the close coordination of APHIS, CDFA, county agricultural officials, the university extension service, industry, and the community. Working together, we were able to convey critical information to growers about the voluntary treatments that were planned. Growers cooperated fully with both the quarantine and treatment plans because the pest was already causing significant damage. It was clear to all involved that we were dealing with a potential game changer for how industry exports and operates.

The quick response, sound scientific strategy, hard work by growers and industry, and the support of the community produced results. If there are no further detections, we expect to remove all EGVM quarantine restrictions and declare complete eradication by the end of 2016 . 
action removed burdensome requirements from growers and homeowners who were often forced to destroy infected plants.

Similarly, we streamlined the Phytopthora ramorum regulatory framework for nurseries shipping host nursery stock interstate, targeting inspections to higher risk nurseries and relieving requirements on 2,800 low-risk nurseries. In our New York PCN program, we adopted a regulatory strategy similar to that used in Idaho, where we regulate infested and associated fields rather than areas along State or county boundaries. This change allowed us to reduce the regulated area in New York by 76 percent and remove more than 960,000 acres from quarantine. Together, these changes allow us and our State partners to focus resources where they are needed most.

\section{Going Beyond Rulemaking To Solve Plant Health Problems}

For nearly 2 years, we have examined existing regulations for flexibilities we haven't used before. In doing so, we considered alternatives to rulemaking when such strategies may be better suited to achieving our goals. This has resulted in more timely actions, deeper and more substantial collaboration with our partners, and lower costs overall, while also enhancing our ability to safeguard plant health and facilitate safe agricultural trade. For example, when we detected flag smut in hard red wheat in spring 2015, we knew it would not be practical or cost effective to mount a traditional regulatory program. Instead, we worked closely with State and industry officials to communicate directly with affected growers about recommended safeguarding measures for harvesting, storing, and distributing wheat from commercial fields where flag smut had been detected. Knowing what was at stake, growers and harvesters willingly carried out the measures to prevent disease spread and keep infected wheat grain out of trade channels, protecting valuable U.S. wheat export markets.
Turning Innovation Into Action Through the Farm Bill

In 2015, PPQ funded more than 430 projects across the United States through Section 10007 of the 2014 Farm Bill. These projects help protect plant health by giving cooperators the funds they need to put their innovative safeguarding ideas into action. For example, the University of Maryland, USDA's Agricultural Research Service (ARS), and apiary specialists in 37 States and Territories launched the first National Survey of Honey Bee Pests and Diseases. This coast-to-coast survey-the most comprehensive one to date for honey bee pests-provides crucial baseline data to gauge colony health, allowing us to detect exotic pest introductions quickly and prevent their spread. ARS also developed a model to identify higher risk points of entry for invasive pests. The tool uses U.S. census and foreign travel data to better understand exotic movement, optimize surveys for early detection, and support proactive resource planning. We applied the model to citrus programs in Florida and are expanding its use to programs in California and Texas.

\section{Supporting U.S. Specialty Crop Production}

Each year, at least $\$ 5$ million of the Farm Bill Section 10007 funding goes to the National Clean Plant Network (NCPN). In 2015, Farm Bill funding supported 24 clean plant centers in 17 States and 1 U.S. Territory. They helped protect U.S. specialty crops by diagnosing harmful pathogens that cause disease in fruit trees, grapes, berries, citrus, hops, sweet potato, and roses; applying therapeutic measures to eliminate those pests; and maintaining clean plant starter material for the covered crops. U.S. nurseries, growers, and breeders use the healthy planting stock to sustain their businesses, maintain productivity, and improve the quality of their products. 


\section{Results}

\section{- Pest detection}

- Detected 91 percent of significant pest introductions before they spread from the area of original colonization

\section{Cotton}

- Kept 99.5 percent of 16 million acres of cotton free from boll weevil

- Continued pink bollworm eradication efforts in the southwestern United States, with no detections in 2015

\section{- Specialty crops}

- Maintained 4,500 clean starter plants across the 7 supported specialty crops: fruit trees, grapes, berries, citrus, hops, sweet potato, and roses

- Continued European grapevine moth (EGVM) eradication efforts in California, resulting in zero detections in 2015 and protecting the $\$ 4.9$ billion grape industry

- Eradicated 10 fruit fly outbreaks and contained an additional 2 outbreaks

- Produced 1 billion sterile flies per week to maintain a 149,000-mile Mediterranean fruit fly-free barrier in Mexico, Guatemala, and Belize and to release in high-risk areas of California and Florida

- Reared and released 100 million sterile Mexican fruit flies weekly to protect the fruit and vegetable industry in Texas' Lower Rio Grande Valley, which includes citrus production worth more than $\$ 73.5$ million

- Coordinated the HLB MAC's \$20 million investment to develop and deploy promising near-term tools and solutionsincluding biological control production and release, thermotherapy, soil acidification, antimicrobials, and early detection technologies la number of which have been delivered to States and industry for use)that will help the citrus industry combat HLB

- Helped more than 5,800 citrus businesses move regulated host materials despite expanding HLB and ACP quarantine areas

- Eradicated plum pox virus from Niagara County, NY

- Prevented potentially infested material from being shipped from a large nursery in the Pacific Northwest that was positive for Phytophthora ramorum, protecting nursery stock production worth approximately $\$ 1.5$ billion

- Continued to make steady progress toward eradicating PCN, with no detections of viable cysts in over half of all infested acres

- Rangeland

- Suppressed grasshopper and Mormon cricket populations on more than 200,000 acres of rangeland in Arizona, Idaho, Montana, Nevada, Utah, and Washington, protecting more than 380,000 acres of rangeland, forage, and wildlife habitat

- Kept imported fire ant from spreading outside current regulated areas

\section{Trees and forests}

- Eradicated 82 percent of the ALBinfested area in New York, 30 percent in Massachusetts, and 8 percent in Ohio

- Continued to successfully slow the spread of the European gypsy moth, eradicating isolated populations as they were detected

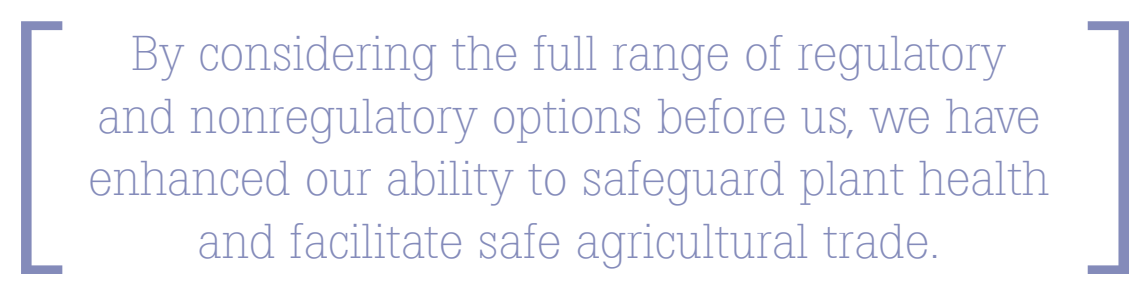




\section{Making Agricultural Trade Safe and Supporting U.S. Exports}

Tn fiscal year (FY) 2015, American farmers

and ranchers exported $\$ 139.7$ billion of food and agricultural goods to consumers worldwide. These exports contribute a trade surplus to America's economy, benefiting rural communities and keeping U.S.-grown products in high demand around the world. At home, U.S. agricultural exports support more than 1 million jobs both on and off the farm.

At the beginning of 2015, we set a goal to increase the safety of agricultural trade and expand economic opportunities in the global marketplace by:

- Promoting the development and use of internationally and regionally harmonized, science-based plant health measures;

- Resolving international plant health issues to reduce trade barriers; and

- Helping exporters manage plant health issues to increase the safety and number of U.S. plant and plant product exports.

\section{Progress Made}

\section{Building International Relationships, Achieving Global Solutions}

One major challenge of global agricultural trade is moving billions of dollars in commodities without spreading invasive pests and diseases. PPQ addresses this challenge by building international relationships based on common plant protection goals. These relationships create a stronger basis for effectively addressing trade-related pest and disease threats, resolving emergency trade problems, and establishing similar and consistent, or harmonized, sciencebased standards. These standards become the rules of the road, sea, and air for safe, predictable, and fair trade. PPQ works actively with international and regional standard-setting organizations such as the International Plant

Protection Convention (IPPC) and North American Plant Protection Organization (NAPPO).

In 2015, PPQ strengthened and deepened these relationships through bilateral trade negotiations, scientific exchanges and technical training events, standard-setting activities, coalition building efforts, and collaborative initiatives with plant health organizations and institutions from around the world. For example, our partnership with Australia, Canada, and New Zealand has become instrumental in advancing shared standard-setting priorities at the IPPC and launching key initiatives of mutual interest that could become a basis for new international standards. We also worked through NAPPO to enrich PPQ's relationships with other regional plant health organizations, including the European Plant Protection Organization, the Organismo Internacional Regional de Sanidad Agropecuaria, and the Inter-American group of Regional

Plant Protection Organizations. These collaborative efforts allowed PPQ and NAPPO to build stronger support around the world on various critical topics such as electronic phytosanitary certificates (e-phytos), workshops to improve worldwide implementation of standards, seed and wood packaging material issues, and priority pests. In addition, we reached an agreement with China's Academy of Agriculture to promote the exchange of scientific information in mutual areas of interest. This precedent-setting agreement signed by PPQ and the Academy reflects our stepped-up relationship with this key emerging economy. 


\section{Making Global Trade More Secure and Efficient}

During the last year, PPQ led a global movement to adopt and use e-phytos. E-phytos increase the safety, security, and efficiency of trade by allowing plant health data to be sent electronically to importing countries. Widespread adoption of e-phytos will lower costs associated with printing and shipping paper certificates, decrease the risk and loss of market share caused by paper certificate transfer wait times, and reduce the number of fraudulent certificates used in trade. We established a two-way exchange of e-phytos with the Netherlands, and we tested the exchange of e-phytos with Mexico, Guatemala, and Peru. In addition, we successfully advocated for international support to fund a global e-phyto hub that will make e-phytos accessible to all trading partners, national plant protection organizations, and their exporters.

\section{Harmonizing How the World Assesses Pest Risks}

Fundamental to a safe, predictable, and fair trade system is a harmonized approach to risk assessment. Our experts worked through

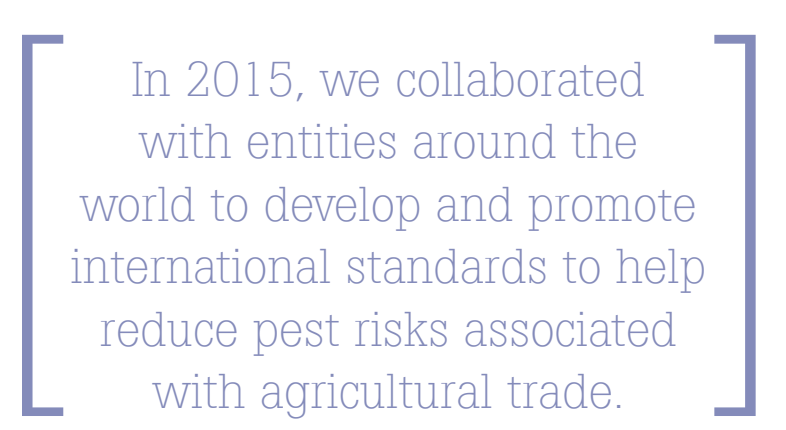
international forums to advocate for a more sciencebased approach to evaluating and regulating risk. When countries consistently apply the least restrictive, technically justified measures, they create trade opportunities without compromising the security of their natural and agricultural resources. To facilitate this, we gave training on the implementation of pest risk assessment standards (ISPM 2 and 11) to foreign regulatory officials from various countries, including Brazil, Canada, India, Mexico, Romania, Malaysia, and Pakistan.

\section{Streamlining Import Processes}

PPQ worked with CBP and 46 other government agencies to begin implementing the International Trade Data System (ITDS)-a governmentwide initiative to streamline import and export processes and facilitate trade. ITDS will eliminate multiple paperbased commodity entry processes and allow importers and exporters to electronically submit their data once into a new system called the Automated Commercial Environment (ACE). To support this effort, we created comprehensive implementation guides that detail APHIS' import data requirements. Software vendors will use these guides to program the systems that importers, brokers, and others in the trade community will use to file their shipments in ACE. We also successfully tested ACE with importers who must file Lacey Act declarations, achieving a 100-percent success rate with no data or system errors. System testing for other commodities, including live plants and plant products, will begin in 2016.

\section{Reducing Pest Threats}

In 2015, we collaborated with entities around the world to develop and promote international standards to help reduce pest risks, especially tree pest threats, associated with agricultural trade. We provided feedback to improve a draft international standard for the movement of wood products - a known pathway for the movement of harmful forest and wood pests. Adoption of this standard will increase our ability to safeguard against the spread of these pests while facilitating the safe trade of bamboo and wood products. In addition, our experts reviewed and commented on draft international standards for two new wood packaging material pest treatments proposed for inclusion in International Standard for Phytosanitary Measure 15 (ISPM 15): Regulation of Wood Packaging Material in International Trade. 


\title{
Case Study
}

\author{
Regaining Access to China's Markets
}

n 1994, the United States began negotiating with China to gain full market access for U.S. apples. Difficult negotiations persisted for 20 years with little progress.

To help realize our goal of full market access, we performed extensive research to demonstrate the safety of U.S. apples. This included a comprehensive risk assessment and pest list showing that most of the 336 pests of concern for China were already established in China or would not likely be introduced by apples. Our trade team also worked with stakeholders and regulatory officials from apple-producing States to document current pest control measures, including fruit handling, inspection, and processing procedures.

Through intense bilateral discussions, site visits, and the exchange of numerous proposals, we reduced the number of pests of concern from 336 to 28 and negotiated operational procedures acceptable to both China and our domestic stakeholders. In addition, we were able to reduce costs for U.S. apple exporters by removing the cold treatment requirement that had been in effect since 1993, when China first granted limited market access.

As a result of these efforts, $\mathrm{PPQ}$ and China finally reached an agreement in January 2015 allowing the export of all apple varieties from across the United States to China. This landmark agreement represents a significant market opportunity for apple growers, packers, and shippers nationwide. Both large and small businesses now have access to sales opportunities in this important market. In 2015 alone, its value was estimated at \$35 million, with significant growth potential in future years. This expanded access may brighten the employment outlook in the more rural areas of apple-growing States.

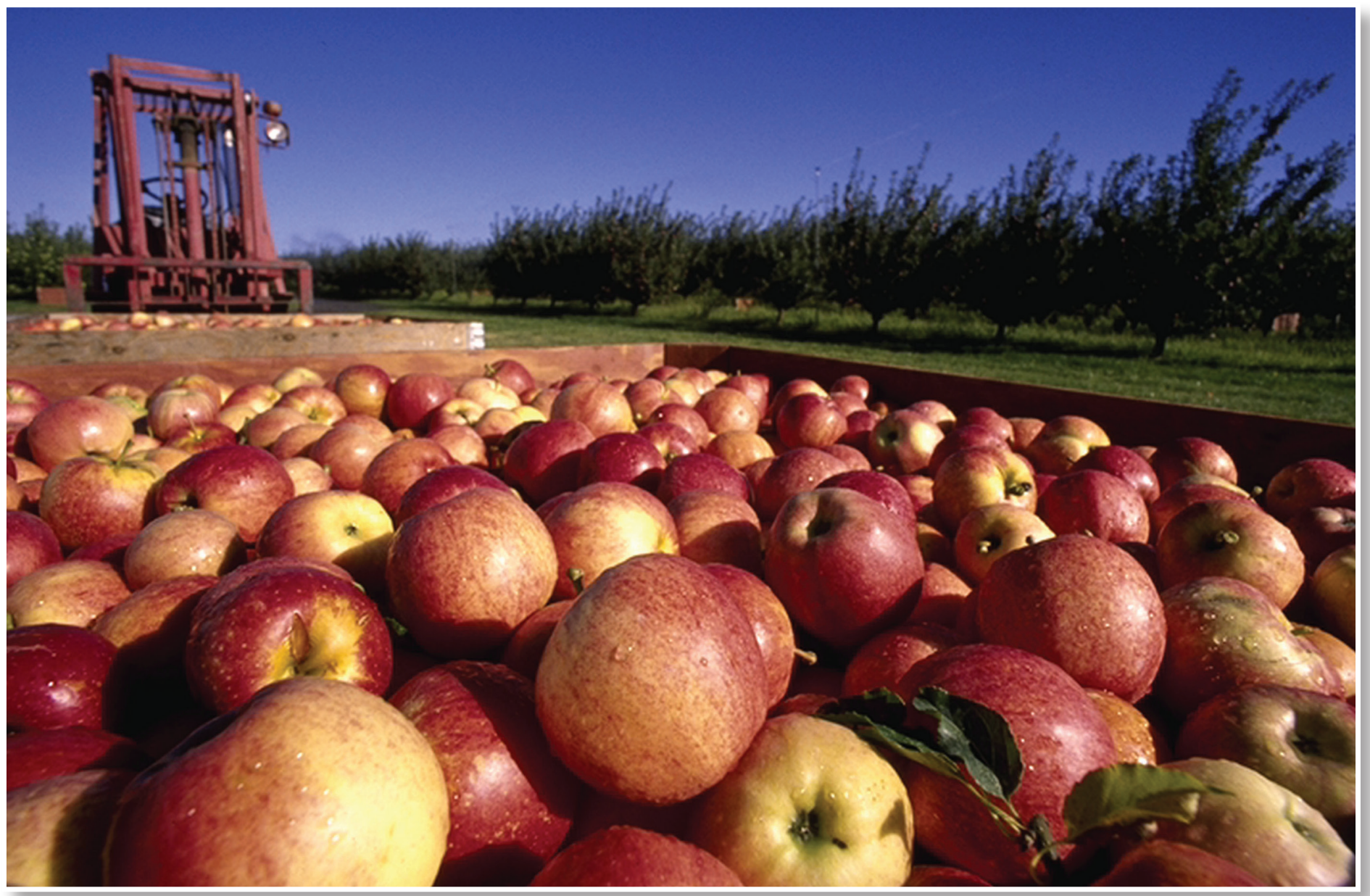


Through NAPPO, we developed standards for managing wood and forest pests. This included: identifying the need for and setting in motion the creation of standards for moving wood under a systems approach; completing the revision of Regional Standard for Phytosanitary Measures 33 (RSPM 33), Guidelines for Regulating the Movement of Ships and Cargo from Areas Infested with the Asian Gypsy Moth; and drafting a paper on the risks associated with tussock moths (Lymantriids) to the North American region, including potential species and pathways of concern. In addition, we helped in developing two multinational workshops focused on tree pests. The first workshop, held in November 2015, helped participating countries develop AGM programs based on the RSPM 33 The second workshop, to be held in the future, will aim to increase global compliance with ISPM 15

\section{Facilitating Exports}

In 2015, PPQ and its State partners issued more than 665,000 phytosanitary certificates, facilitating the movement of agricultural commodities worth billions of dollars. We also made improvements to better meet stakeholder needs. For example, we aligned our export certification coverage areas and strategically located export certification officers to provide quicker service. We also increased export certification of processed commodities. Together, these actions helped us better meet industry needs, resulting in improved service to U.S. exporters. In addition, we developed a framework that would allow private laboratory test results to be used in support of export certification. We plan to pilot the process in 2016. If successful, exporters will have more opportunities to get the high-quality, reliable tests they need to meet importing countries' plant health requirements.

\section{Sustaining and Expanding Key Export Markets}

We supported U.S. exports by resolving plant health issues and removing trade barriers, opening new and retaining existing markets for U.S. agricultural products. One of our greatest achievements was a new agreement with China. After 20 years of negotiation, we opened two-way trade of apples between our countries. Another significant achievement included working with Japan to obtain approval to transport U.S. chipping potatoes overland from a Japanese port of entry to an inland processing plant. As confidence in the shipments increases, more processing facilities will become available to further increase U.S. chipping potato exports to this important market. We also negotiated the continued on-arrival fumigation for California citrus to Korea-the top market for California citrus-for the 2015/2016 season. 
Working with Mexico, we negotiated oversight

transfer agreements for three U.S. commodities:

California stone fruit, California apples, and

Michigan and Virginia apples. These agreements

reduce burdens and costs associated with

oversight activities, making this a more cost-

effective market for these commodities.

We worked quickly with the Kansas Department of Agriculture to survey an outbreak of wheat flag smut detected in that State. We used the survey results to demonstrate the limited distribution of the disease and preserve U.S. market share for hard red winter wheat. We were also able to quickly reopen the Chinese market for California citrus from Tulare County less than a year after China closed it due to pest interceptions. And we successfully used data from our fruit fly survey and eradication programs to reassure trading partners that we are effectively dealing with the recent fruit fly outbreaks, helping to support U.S. market share for a number of important commodities.

\section{Results}

- Expanded market access for all U.S. apple varieties to China, with an estimated value of over \$35 million in 2015

- Maintained market access for California stone fruit, California apples, and Michigan and Virginia apples to Mexico valued at \$62 million while reducing oversight burdens and costs

- Expanded the Japanese market for chipping potatoes valued at more than $\$ 7$ million

- Maintained market access for California citrus to Korea, the top market for this commodity, estimated at \$225 million

- Protected more than $\$ 800$ million in annual sales of hard red winter wheat to 16 countries that regulate for flag smut

- Facilitated the timely release of more than 250 U.S. shipments - valued at more than \$63 million-that were held at foreign ports of entry

- Negotiated the first-ever use of irradiation for exports, resulting in the export of 1,440 boxes (37,800 pounds) of irradiated peaches from South Carolina to Mexico 


\section{Working for PPQ's Employees}

$P P$ 'S $\begin{aligned} & \text { employees are its greatest asset. } \\ & \text { We can only realize all of our }\end{aligned}$ important accomplishments with a talented, committed, and well-trained workforce. In 2015, we invested in our workforce and took steps to help them prepare for the future. We focused our efforts in two areas:

- Encouraging and supporting development, knowledge retention, collegiality, innovation, and safety; and

- Valuing and leveraging the differences offered by a diverse workforce.

\section{Progress Made}

\section{Increasing Training and Development Opportunities}

We increased employee development efforts and offered training to enhance leadership skills. We supported training in areas such as innovation in government, managing a multigenerational workforce, risk communications, collaborative management, implementing effective internal controls, cultural awareness, accountability, and working with international partners, among others. To provide more opportunities for employee success, we put procedures in place for conducting quarterly progress reviews to help increase the frequency of supervisor-to-employee feedback.

We also provided training to strengthen our employees' technical capabilities in agricultural safeguarding, disease diagnostics, pest identification and detection, risk analysis, phytosanitary treatments, detector dog handling, and plant health emergency response, among others. These trainings ensure that our workforce is equipped with the knowledge and skills needed to be successful now and in the future.
In addition, our Professional Development Center provided technical training to CBP employees, State department of agriculture personnel, foreign ministries of agriculture, and U.S. military cooperators. These trainings help prepare our partners and cooperators to carry our critical safeguarding activities offshore, at U.S. ports of entry, and across the country.

\section{Improving Employee Safety and Health}

The PPQ Management Team is committed to not only maintaining but also improving safety and health in PPQ. Our goal is to reduce accidents, injuries, and occupational illnesses by building employee knowledge and reducing the primary threats to employee safety and health. Last year, we conducted the first-ever, PPQ-wide "Stand Down for Safety" event aimed at making PPQ a safer, healthier place to work. On May 6, 2015, PPQ offices around the country stopped to talk about and document their safety and health concerns. In response, we created action plans to address the issues employees raised.

In addition, we provided timely information throughout the year to employees on a range of topics, including chemical storage and handling, trailer towing, all-terrain vehicle use, communications in remote areas, public health threats like Ebola, and what to do if confronted by an active shooter, among others. We also developed a form for employees to anonymously identify concerns without fear of repercussion. In our laboratories, we conducted a thorough review of those facilities to find and fix issues that could impact employee safety and health.

\section{Refining PPQ's Structure}

In 2015, we brought together our seniorlevel managers to address administrative and operational inconsistencies across our 
organization and help improve communication up, down, and across PPQ. In addition, we restructured two Plant Health Program divisions to establish more reasonable supervisor-toemployee ratios, improve planning and workflow, and create more manageable workloads for employees. To increase our ability to deliver high-quality, mission-oriented training to employees and our partners, we restructured our Professional Development Center and created the Leadership Development, Distance Learning, and Organizational and Planning Support units. We also explored options to improve our Field Operations' (FO) organizational structure to strengthen program delivery, improve supervisor-to-employee ratios, analyze the need for more field supervisory positions, and improve communication and coordination within FO and with other parts of PPQ.

\section{Recruiting and Hiring}

PPQ leaders identified a key operational challenge: a large number of vacant positions and the long time taken to fill them. To tackle the issue, the PPQ Management Team created the Workforce Stability Team to streamline hiring and lessen the overall impact caused by vacancies. Since May 2015, team members have been examining the recruitment process' multiple steps and each step's average timeline. The Team has also been working to resolve the backlog of position announcements and better prioritize recruitment efforts.

\section{Planning for PPQ's Future}

With many PPQ employees at or nearing retirement and an influx of new hires, we took steps to prepare our changing workforce for the future. We began work on a PPQ Human Capital Plan that will help us anticipate human resource needs to deliver PPQ's mission today and in the future. We also gave many opportunities for employees to temporarily serve in a variety of roles, such as analysts and State Plant Health
Directors, to enhance their professional growth. In addition, we began using overlapping positions to transfer knowledge from retiring employees to new hires.

To give opportunities to aspiring leaders, we reinvigorated the Developmental Assignment Program. This program allows employees to stretch professionally and take on assignments that benefit PPQ. We also started the first Plant Health Programs Career Ladder Program to help bridge gaps in knowledge management, succession planning, and employee development. This program offers participating employees crosstraining, leadership development, and knowledgesharing opportunities.

\section{Results}

- Filled 346 vacancies, including 10 State Plant Health Director and 77 PPQ officer positions

- Converted 124 term positions to permanent ones and continued to work on converting 36 more, helping to stabilize the workforce by reducing turnover rates and the loss of institutional knowledge that comes with term appointments

- Reduced the average length of time a selecting official possesses a hiring certificate from 34 days to 23 days, helping to bring PPQ in line with soon-to-be mandated hiring timelines

- Provided training to more than 5,600 PPQ employees, State department of agriculture personnel, CBP employees, and foreign ministries of agriculture staff

- Signed a collective bargaining agreement with the National Association of Plant Protection and Quarantine Office Support Employees (NAPPQOSE), replacing a 10-yearold agreement, marking the culmination of years of work with the union, and fostering a new relationship with NAPPQOSE that will promote and improve the efficient administration of PPQ 


\section{Recognizing PPQ's Employees}

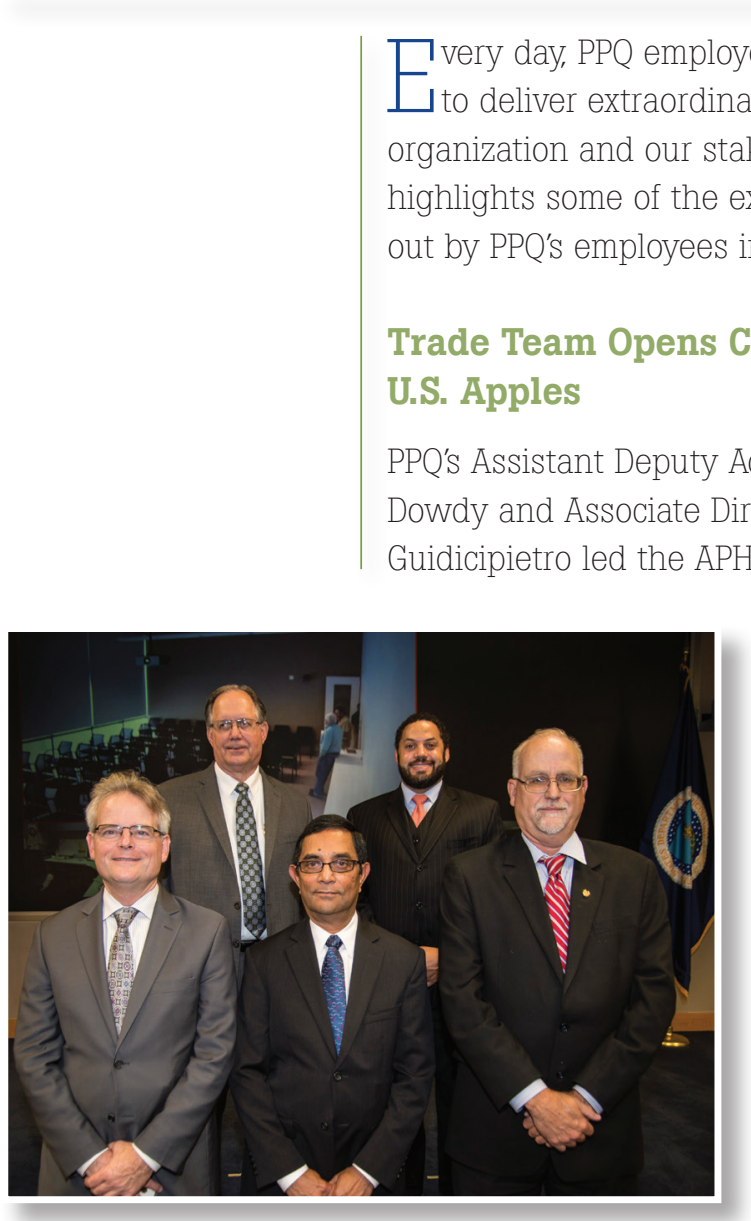

$\triangle$

Shown (back row, left to right) APHIS Associate Administrator Jere Dick and USDA Marketing and Regulatory Programs Deputy Under Secretary Gary Woodward and (front row, left to right) APHIS International Services' Sanitary Phytosanitary Trade Policy Director Russ Caplen and PPQ's Senior Risk Managers-Entomology Devaiah Muruvanda and Walter Gould. access to sales opportunities in a potential market of 1.3 billion people. And this expanded access may brighten the employment outlook in the more rural areas of apple-growing States.

Members of the U.S. Apples to China team included: Robert Bishop, Lottie Erickson, Walter Gould, Walter Gutierrez, Jose Hernandez, Wenbin Li, Judy Macias, Devaiah Muruvanda, Scott Redlin, Nicole Russo, and James Smith from PPQ; Russell Caplen, Lou Vanechanos, and Xu Yan from APHIS International Services; and Mayra Caldera from USDA's Foreign Agricultural Service.

Shown (back row, left to right) are Agriculturist Gregg Goodman, APHIS Associate Administrator Jere Dick, and USDA Marketing and Regulatory Programs Deputy Under

Secretary Gary Woodward and (front row, left to right) Agriculturist Renee Devries, Agriculturist Vickie Brewster, and Containment Scientist Ingrid Asmundsson.

\section{Permit Team Greatly Improves Pest Permit Process}

Issuing permits for the movement of regulated materials is a crucial element of PPQ's mission.

Through a business process improvement initiative, Agriculturist Vickie Brewster and former Pest Permit Branch Assistant Director Shirley Wager-Page (now retired) led a team that achieved significant and measurable reductions in costs and processing time for issuing microbial and other pest permits.

The initiative cut the overall time required to process a PPQ 526 Permit by 11 days, a 23-percent reduction. By transitioning from paper shipping labels to downloadable electronic labels, PPQ eliminated the need to print and mail physical labels to importers, saving the program $\$ 351,000$ in annual labor costs. Importers can now email the electronic file to their shippers, saving these stakeholders an estimated \$125,000 annually. These improvements greatly benefited PPQ as well its stakeholders.

The Pest Permit Improvement Team included: Ingrid Asmundsson, Vickie Brewster (co-group leader), Renee DeVries, Gregg Goodman, Monica O’Neil, Lena Soileau, Mark Stull, Shirley WagerPage (co-group leader, now retired), Michael Watson, and Wayne Wehling.

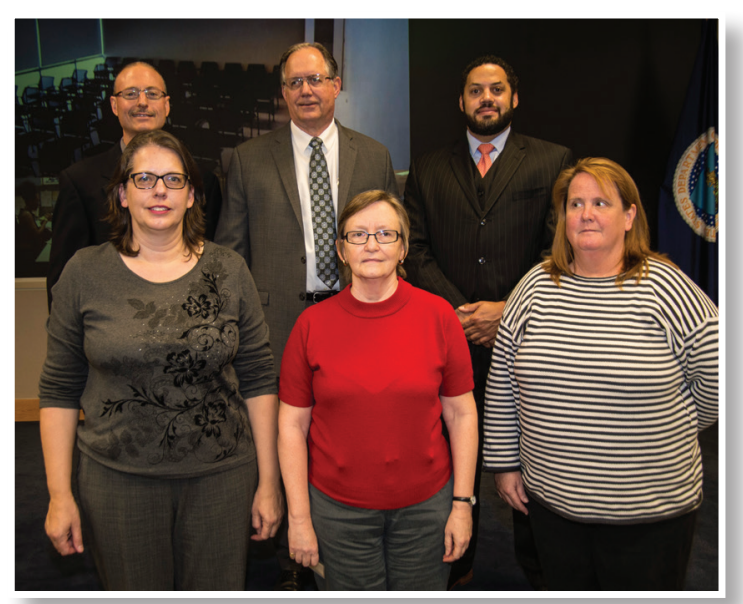




\section{PPQ Fruit Fly Expert Supports New Trilateral Agreement}

PPQ's National Fruit Fly Policy Manager John Stewart served on a USDA team that successfully negotiated a new agreement with Mexico and Guatemala to strengthen America's safeguarding capability against damaging exotic fruit flies. Stewart provided critical technical expertise gained through years of domestic and international experience with APHIS' Fruit Fly Exclusion and Detection (FFED) program. He helped ensure the new agreement's language was harmonized with the FFED's strategic goals and objectives: preventing the spread of exotic fruit flies into and through Mexico, reducing the fruit fly pressure in Guatemala and throughout the region, and ensuring a continuing source of high-quality sterile insects for U.S. fruit fly prevention and eradication programs.

Over the past 30 years, the United States has negotiated individual agreements with Mexico and Guatemala through the Moscamed program to prevent, control, and eradicate the Mediterranean fruit fly (medfly) and other economically significant fruit fly pests. The efforts of the USDA negotiation team resulted in a new trilateral agreement that was signed and effective on February 12, 2015, an impressively quick timeframe for such a negotiation. The agreement established a legal framework to continue operations through the newly formed MOSCAMED Commission. This commission is responsible for overseeing the continuation, modernization, and expansion of the current medfly program and other fruit fly pests of economic importance.

By preventing medfly introductions into Belize, Mexico, and medfly-free areas of Guatemala and the United States, the program protects the multibillion dollar U.S. fruit and vegetable industry. These efforts directly support the prosperity and sustainability of rural economies.

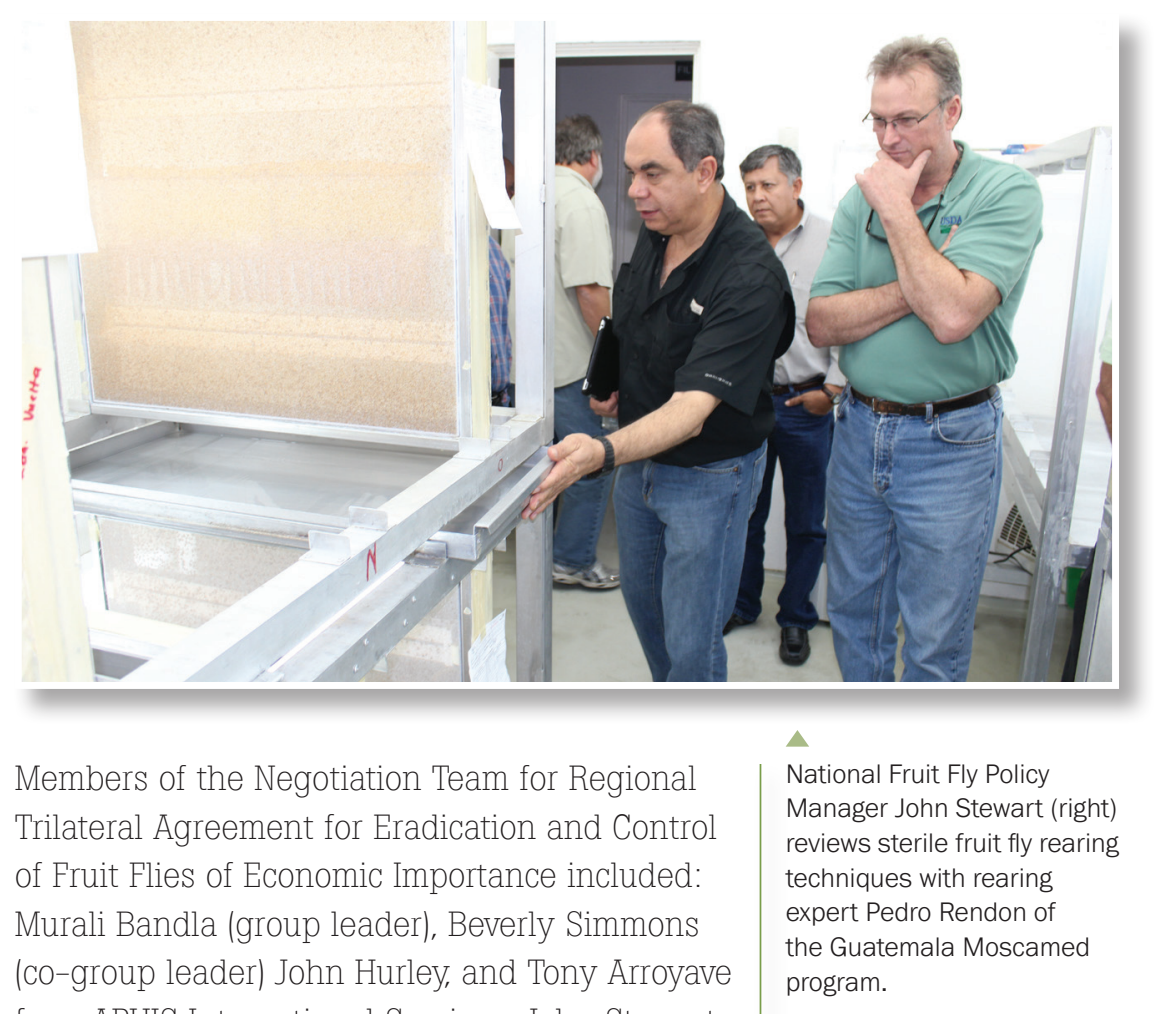

from APHIS International Services; John Stewart from PPQ; James Booth, Ciarra Toomey, and Antonio Robinson from USDA's Office of the General Counsel; and Jeffrey Kovar from the U.S. Department of State.

\section{PPQ Medical Officer Helps Fight Agricultural Diseases in West Africa.}

PPQ Veterinary Medical Officer Connie Bacon received an Administrator's Award for her contributions to fighting highly pathogenic avian influenza in West Africa. Her team, led by APHIS International Service's Agriculture Science Officer Cheikh Fall and the United Nations' Food and Agriculture Organization's (FAO) Regional Manager Charles Bebay, helped to advance global food security-a major goal for U.S. Secretary of Agriculture Tom Vilsack.

When confronted with multicountry outbreaks of highly pathogenic avian influenza in 2007, APHIS joined forces with FAO's Emergency Center for Transboundary Animal Diseases (ECTAD). The team's goal was to provide technical assistance and capacity building to 
launch West Africa's first regional laboratory and surveillance network. Bacon joined the effort in 2010 when she began a 4-year detail as the U.S. Agency for International Development's Sanitary and Phytosanitary Advisor for West Africa. That detail took her to 20 countries across Africa as a senior-level advisor for technical assistance programs, training, and capacity-building workshops related to agricultural health and food safety in West Africa.

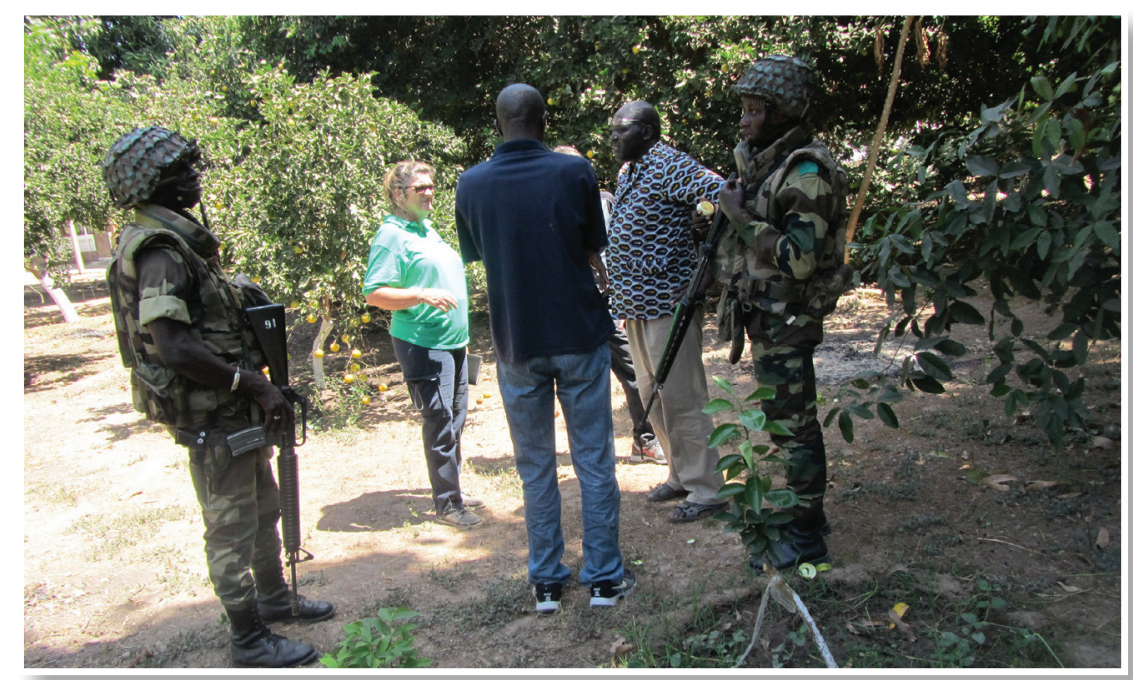

$A Q I$ Veterinary Medical Officer Connie Bacon (second from left), escorted by Senegalese soldiers due to security concerns, discussed fruit fly biological controls with Senegal's Chief Entomologist Kemo Badji (second from right).
The results were the West and Central Africa Veterinary Laboratory Network (RESOLAB) and the Regional Epidemio-Surveillance Systems Network (RESEPI), which in 2014 came under the full control of the African countries involved. These nations are now prepared for agricultural disease challenges.

The APHIS Dakar and FAO ECTAD-Bamako Team for RESOLAB and RESEPI Handover included: Cheikh Fall (co-group leader), Morella DeRosa, Russell Duncan, Jessica Mahalingappa, Mark Prescott, and Moustapha Seye from APHIS International Services; Connie Bacon from PPQ; Charles Bebay and Boubacar Seck (receiving the award posthumously) from the FAO; and Yacouba Samake and Abdoulaye Niang (also receiving the award posthumously) from the World Organization for Animal Health's Regional Commission for Africa.

\section{PPQ Laboratory Earns World Gold- Standard ISO 17025 Certification}

In June 2015, PPQ's Center for Plant Health Science and Technology laboratory located in Beltsville, MD, successfully earned accreditation from the International Organization for Standardization (ISO)/International Electrotechnical Commission (IEC) under the 17025 standard. The American National Standards Institute-American Society of Quality National Accreditation Board completed its accreditation audit and found that the laboratory, led by Mark Nakhla, had a sound quality management system and demonstrated the technical competence needed for compliance with internationally recognized standards for laboratory test performance and competence. The laboratory's initial scope of accreditation is for confirmatory diagnostics of citrus greening, plum pox virus, and Phytopthora ramorum. This PPQ facility is the first regulatory plant diagnostic laboratory in the United States to obtain this prestigious accreditation.

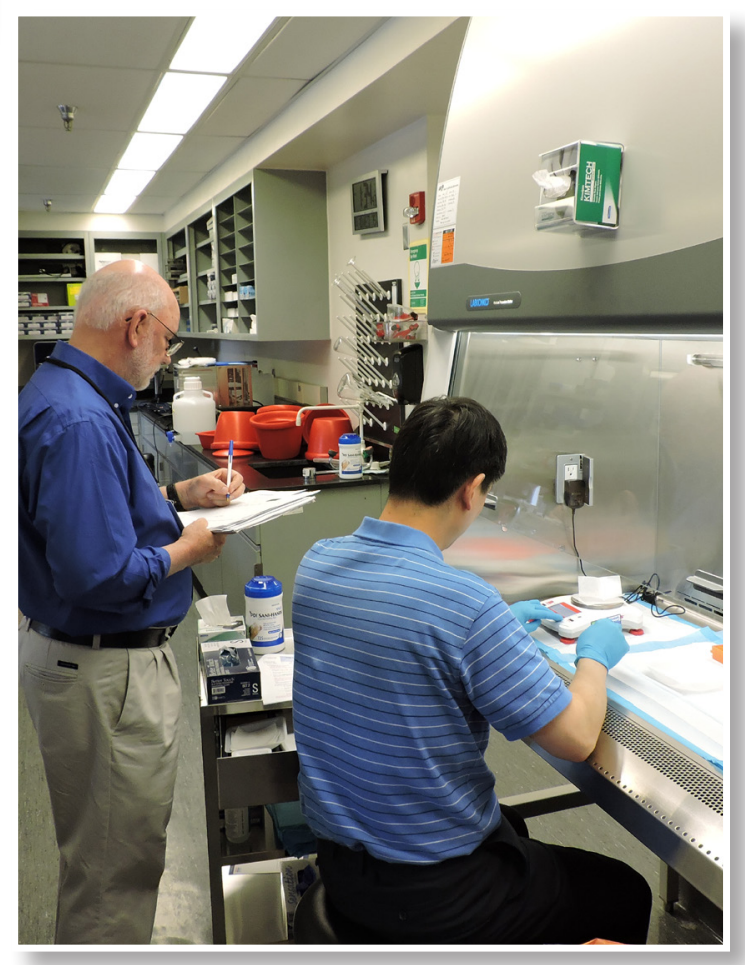

Shown (left to right) are American National Standards InstituteAmerican Society for Quality National Accreditation Board auditor Bill Hirt and APHIS Fellow Zhonghe Yan. 


\section{PPQ Technician Solves Mystery, Stops Sterile Fruit Fly Die-Off}

In early 2014, sterile Mexican fruit flies at PPQ's mass-rearing facility in Edinburg, TX, began dying at an increasing rate. The Mexican fruit fly program faced a serious threat to its mission and needed to find the cause-and fast. Each week, the program releases more than 100

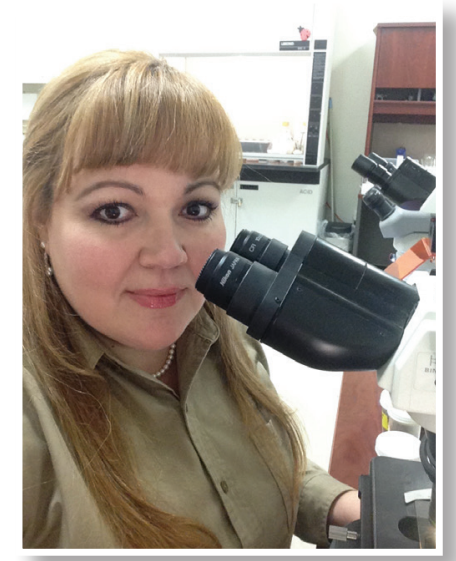

Biological Sciences Technician Sandra Leal million sterile Mexican fruit flies throughout southern Texas. They protect the State's fruit and vegetable crops by preventing newly introduced wild Mexican fruit flies from successfully reproducing. Texas' citrus industry alone

had a production value of more than $\$ 73.5$ million in 2014.

Fortunately, Sandra Leal, a Biological Sciences Technician out of the program's Harlingen, TX, office, was on the case. Calling on her background in medicine and her entomological expertise, in November 2014, Leal identified abdominal parasites infesting the flies. The parasites were associated with a nematode and bacterial infestation at the Edinburg facility. Leal conducted detailed epidemiology research and detected the source of infection: contaminated corn cob used to prepare the flies' diet media.

Leal worked with PPQ's Center for Plant Health Science and Technology and USDA's Agricultural Research Service to develop a ground-breaking protocol to control and prevent the nematodes, parasites, and bacteria that were plaguing the sterile flies. Their practical solution can now be used in other sterile insect programs to prevent similar issues, likely benefiting sterile insect technology programs around the world.

This work safeguarded PPQ's fruit fly colonies, provided healthier flies for field release, and saved PPQ significant costs in potential lost production capacity.

\section{USDA Gives Top Award to APHIS-PPQ Labor-Management Forum Team}

On November 5, 2015, Secretary of Agriculture Tom Vilsack presented an Abraham Lincoln Honor Award-the Department's highest honorto the APHIS-PPQ Labor-Management Forum team, marking the first time that an Honor Award has ever been presented to APHIS. The forum, created in 2011 and overseen by team leaders Sarah Rehberg and Cynthia Ross, epitomizes collaborative excellence between labor and management.

The forum's work has strengthened labormanagement relations and helped to improve morale. The team developed and delivered numerous training sessions that explain why collective bargaining and pre-decisional

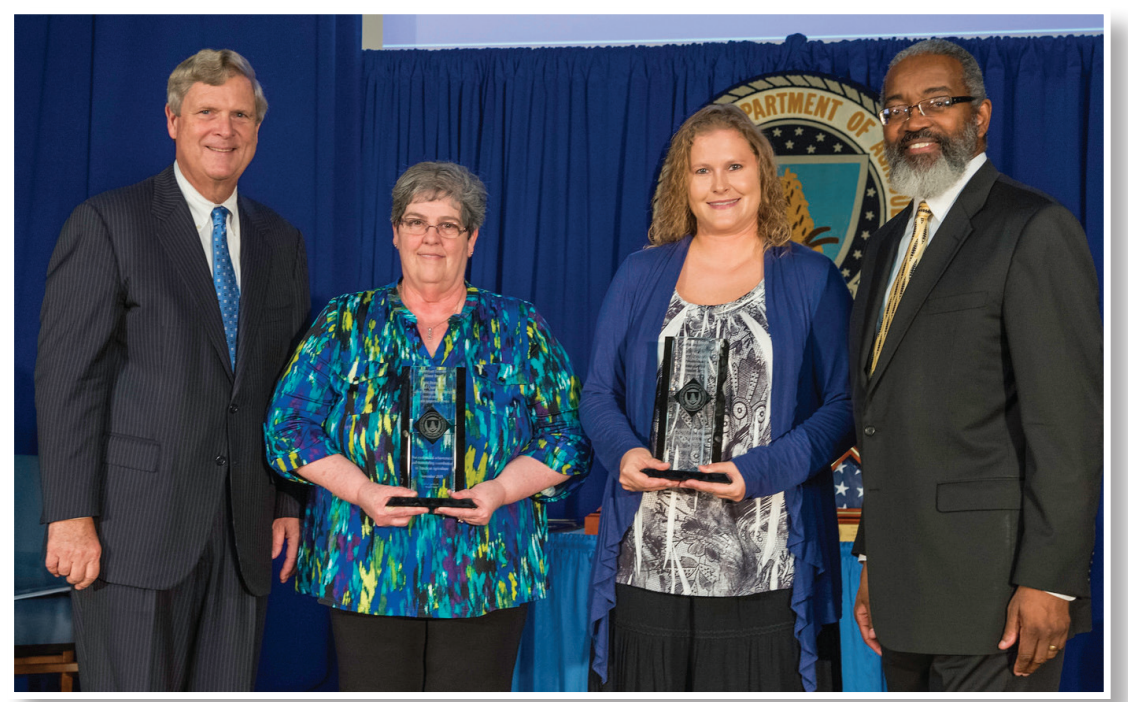

Shown (left to right) are Secretary of Agriculture Tom Vilsack, APHIS-PPQ Labor-Management Forum group leaders Cynthia Ross and Sarah Rehberg, and USDA Assistant Secretary for Administration Gregory Parham. 
involvement are vital to PPQ's success. In addition, team members deftly used social media to celebrate the successes and talents of PPQ employees.

In fact, the forum's outreach efforts have been so well-received that it captured the National Council on Federal LaborManagement Relations' attention. As a result, this forum has become the benchmark for labor-management relations excellence throughout the Federal Government.

The APHIS-PPQ Labor-Management Forum team includes: Peter Brownell, Robert Hostetter, Frank King, Mike Lidsky, Carlos Martinez, Keith Miller, Michael Randall, Sarah Rehberg (co-group leader), Cynthia Ross (co-group leader), Pamela Schoen, Julie Shepherd, James Triebwasser, Arlo Wiltenburg, and Regina Wolf.

\section{PPQ Supports the U.S. Department of Defense's Operation Talisman Sabre}

Beginning in March 2015, PPQ supported the DoD's Talisman Sabre, a biennial military exercise between the United States and Australia. This exercise is a unique opportunity for the countries to test their capacity for contingency response and the interoperability of their equipment, tactics, techniques, and procedures.

Australia requires that imported military equipment be compliant with stringent biosecurity protocols. However, U.S. military regulations prohibit foreign authorities from boarding and conducting the necessary inspections. To facilitate the exercise, PPQ's Talisman Sabre team served aboard U.S. Navy vessels and conducted preinspections of military equipment and eliminated all agricultural risks discovered during the process. This included the inspection and certification of 41 combat aircrafts, 5 amphibious vessels, and all of the vehicles and equipment used by the participants. These efforts allowed DoD to practice on the Australian shores.

The PPQ Talisman Sabre team includes: Jose Lozada, Lee Newport, William Aley, JoAnn Cruise, and Colleen Kitzmiller.

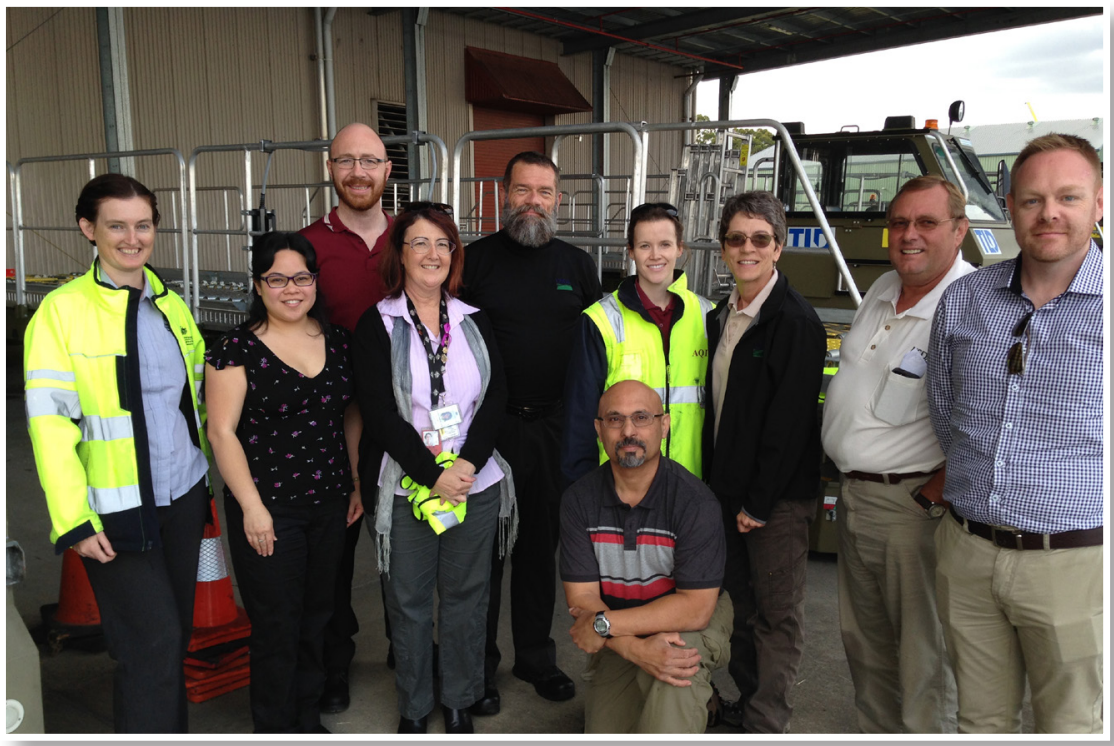

Shown (left to right) are: Nicole Harvey (Aus.), Michelle Brotohusodo (Aus.), Andrew Agius (Aus.), Leonie Kearney (Aus.), Bill Aley (PPQ), Emma Davidson (Aus.), JoAnn Cruse (PPQ), Lee Newport (PPQ), Jon Bicket (Aus.), and (kneeling front) Jose Lozada (PPQ). 
Photo Credits: The row crops (cover), vineyard (page 10), and harvested oranges (page 16) photos are from iStock. The container ship photo shown on the cover and on page 3 is from Shutterstock. The photo of container ships at port on page 4 is from ingimage.com. All other images in this publication are USDA file photos, unless otherwise indicated.

In accordance with Federal civil rights law and U.S. Department of Agriculture (USDA) civil rights regulations and policies, the USDA, its Agencies, offices, and employees, and institutions participating in or administering USDA programs are prohibited from discriminating based on race, color, national origin, religion, sex, gender identity (including gender expression), sexual orientation, disability, age, marital status, family/parental status, income derived from a public assistance program, political beliefs, or reprisal or retaliation for prior civil rights activity, in any program or activity conducted or funded by USDA (not all bases apply to all programs). Remedies and complaint filing deadlines vary by program or incident.

Persons with disabilities who require alternative means of communication for program information (e.g., Braille, large print, audiotape, American Sign Language, etc.) should contact the responsible Agency or USDA's TARGET Center at (202) 720-2600 (voice and TTY) or contact USDA through the Federal Relay Service at (800) 877-8339. Additionally, program information may be made available in languages other than English.

To file a program discrimination complaint, complete the USDA Program Discrimination Complaint Form, AD-3027, found online at How to File a Program Discrimination Complaint (www.ascr.usda.gov/filingprogram-discrimination-complaint-usda-customer) and at any USDA office or write a letter addressed to USDA and provide in the letter all of the information requested in the form. To request a copy of the complaint form, call (866) 632-9992. Submit your completed form or letter to USDA by: (1) mail: U.S. Department of Agriculture, Office of the Assistant Secretary for Civil Rights, 1400 Independence Avenue, SW, Washington, D.C. 20250-9410; (2) fax: (202) 690-7442; or (3) email: program.intake@usda.gov.

USDA is an equal opportunity provider, employer, and lender. 
www.aphis.usda.gov/plant_health

www.aphis.usda.gov/plant_health 